\title{
Understanding the relationship between smoking and place across multiple places through the lens of place attachment
}

Parry, Sara; Hassan, Louise

\section{Journal of Environmental Psychology}

DOI:

10.1016/j.jenvp.2019.02.009

Published: 01/04/2019

Peer reviewed version

Cyswllt i'r cyhoeddiad / Link to publication

Dyfyniad o'r fersiwn a gyhoeddwyd / Citation for published version (APA):

Parry, S., \& Hassan, L. (2019). Understanding the relationship between smoking and place across multiple places through the lens of place attachment. Journal of Environmental Psychology, 62(April), 115-123. https://doi.org/10.1016/j.jenvp.2019.02.009

\footnotetext{
Hawliau Cyffredinol / General rights

Copyright and moral rights for the publications made accessible in the public portal are retained by the authors and/or other copyright owners and it is a condition of accessing publications that users recognise and abide by the legal requirements associated with these rights.

- Users may download and print one copy of any publication from the public portal for the purpose of private study or research

- You may not further distribute the material or use it for any profit-making activity or commercial gain

- You may freely distribute the URL identifying the publication in the public portal ?
}

Take down policy

If you believe that this document breaches copyright please contact us providing details, and we will remove access to the work immediately and investigate your claim. 


\title{
Ref: JEVP_2018_381
}

Understanding the relationship between smoking and place across multiple places through the lens of place attachment

\begin{abstract}
This article explores the psychological processes of place attachment across multiple public and private places and makes an empirical contribution in a smoking context. The study focuses on the range of places that smokers use, the place attachment process within those places, and the relevancy of place for the self-concept. A qualitative approach was adopted and consisted of interviews with 30 UK smokers. Three themes capture the processes by which smokers form attachments to smoking places, namely: seclusion and concealment, sociality, and control. Although smokers' attachments with public and private places are grounded in their daily routine or habit, the person-place bond occurs depending on the benefits that are sought, and the meanings ascribed to the places. In some circumstances the traditional notion of a private place is challenged as public places are re-signified as private places. Overall, our findings provide additional insights into the processes of place attachment in an under-explored behavioral context.
\end{abstract}

Keywords: smoking; place attachment; private places; public places; control; seclusion; concealment; sociality; territoriality 


\section{Introduction}

Place attachment is a multifaceted phenomenon concerning how individuals interact and emotionally bond with places (Low \& Altman, 1992). The concept originates from socio-cultural, psychological, and environmental theories and has been applied in a wide range of social science disciplines (Lewicka, 2011). Place attachment studies have focused on understanding public and private places that vary in scale such as cities, neighborhoods and homes (Gross \& Brown, 2008; Lewicka, 2011; Low \& Altman, 1992). Place attachments can vary from attachment to (a) a specific place or (b) a generic class of place (referred to as settlement identity; Feldman, 1990). Tuan's (1977) view of a spatial unit covered everything from an individual's favorite armchair to the whole earth. Generally, place attachment theory has been applied to broader contexts such as natural resource management (Williams \& Vaske, 2003), migration (Rishbeth \& Powell, 2013), natural disasters (Knez, Butler, Sang, Ångman, Sarlöv-Herlin, \& Åkerskog, 2018), and tourism (Gross \& Brown, 2008), which emphasize larger spatial units.

Places can be distinguished in the extent to which they are public versus private. A public place typically provides freedom of action, accessibility, and temporary ownership (Carr, Francis, Rivlin, \& Stone, 1992). Public places are distinguished from private places "in terms of accessibility, the source and nature of control over entry to a space, individual and collective behavior sanctioned in specific spaces, and rules of use...private space is demarcated and protected by state-regulated rules of private property use" (Smith \& Low, 2006, pp. 3-4). In public places, individuals are bound by social norms and regulations that support public order (Goffman, 2008). However, due to various interpretations of the meaning of public versus private places, this distinction has become ambiguous (Dixon, Levine \& McAuley, 2006), bringing forth the finer- 
grained categorization of private, semi-private, semi-public and public places (Lewicka, 2011). Sheller and Urry (2003, p.115) echoed this distinction when they suggested that the car is a "rolling private-in-public space.”

Place attachment research has centered on refining the concept of place attachment (e.g., Scannell \& Gifford, 2010), testing the predictive ability of place attachment conceptualizations (e.g., Strzelecka, Boley, \&Woosnam, 2017) and its association with related concepts such as place identity and sense of place (Hidalgo \& Hernandez, 2001; Scannell \& Gifford, 2010). These research efforts typically take a place or a collection of places as the central starting point of investigation. Our research focuses on one behavior, namely smoking, as a lens to examine the processes of multiple place attachments. Taking this lens allows us to advance understanding on the processes of multiple place attachments which is understudied.

Legislation restricting smoking within public places has resulted in a number of positive behavioral changes including reduced smoking rates (The Independent, 2017). However, the extent to which such legislation has affected smokers' attachments to private, and the remaining public smoking areas, is unclear. One can form stronger bonds and a sense of ownership in private places. As a result, these (private) sites might be more important to smokers. The continued stigma associated with smoking may influence smokers' choice of smoking sites (Ritchie, Amos \& Martin, 2010(a)). Chosen smoking sites may afford comfort and satisfaction, acquiring symbolic meaning and cognitively, affectively and behaviorally affect attachment (Gustafson, 2001; Stedman, 2002). As such, smoking provides a novel context in which to explore place meaning making.

\section{Smoking and place related policies}


Most legislation concerning smoking focuses on public places both indoor (e.g. restaurants, bars) and outdoor (e.g. beaches, playgrounds). Homes are private, unregulated places where nonsmokers living with smokers suffer from second-hand smoke (SHS) (Mbulo et al., 2016); however, the increased awareness of dangers of SHS is prompting change. In the US, public housing agencies are required (effective from July 30,2018) to implement a smoke-free policy banning smoking in all public housing living units and indoor common areas (Housing and Urban Development Department, 2016).

Following the introduction of public smoking restrictions, studies suggest that many smokers have cut down or quit smoking (Ritchie, Amos, \& Martin, 2010(b)) or increased self-imposed smoke free rules within private places (homes and cars) (Ferketich et al., 2014; Martinez-Sanchez, Fernandez, \& Gallus, 2014). However, the impact of these changes on individuals' place attachment, is unclear. Ritchie et al. (2010(b)) reveal that smokers engaged in a process of both social and behavioral adjustment by modifying their use of public places and habits to the benefits of non-smokers. Passey, Longman, Robinson, Wiggers, and Jones (2016) reported difficulties in maintaining a smoke free home including gaps in understanding of the risks of SHS, lack of agency or control, and maintaining harmony of social relationships. Studies have also discovered that smokers, although principally in agreement with the restrictions, are feeling stigmatized, and believe that smoking has created undesirable social identities (Bell, Salmon, Bowers, Bell, \& McCullough, 2010). Despite evidence of the benefits of creating 'home policies' to protect others from SHS, it is unclear how these rules, in addition to changing social and behavioral practices, are affecting smokers' attachment to their smoking places. Importantly, the literature has not addressed the importance and implications of place attachment for smokers. 


\section{Place Attachment}

Kalandides (2011, p. 36) argued that a place is dynamic, fluid and "becomes an open-end process" consisting of interactions among various social actors. Tuan (1977, p. 6) asserted that space becomes a place when it is filled with meaning and individuals "endow it with value." Place attachment is defined as an emotional connection to a place, which develops over time (Low \& Altman, 1992). Studies show that people develop meaningful attachments to places thus displacement from places can have negative emotional consequences (Brown \& Perkins, 1992; Knez et al., 2018; Sim, Fazel, Bowes, \& Gardner, 2018). The place attachment concept is multidimensional; related to topophilia or love of place (Tuan, 1990), place identity (Hernandez, Martín, Ruiz, \& Hidalgo, 2010), and place dependence (Low \& Altman, 1992; Raymond, Brown, \& Weber, 2010; Rosenbaum, Ward, Walker, \& Ostrom, 2007; Stedman, 2002). The concept of place attachment has been incorporated into the definition of the self, and is linked to the formation, maintenance, and preservation of identities (Low \& Altman, 1992; Proshansky, Fabian, \& Kaminoff, 1983; Stedman, 2002). Indeed Stedman (2002, p. 564) argued that a 'person-place merger' occurs when an individual is attached to a place.

In an effort to summarize the various definitions of place attachment, Scannell and Gifford (2010) proposed the tripartite person-process-place framework which encapsulates three dimensions of place attachment. The 'person' dimension includes both the individual, or personal connection to a place, and the collective, whereby the attachment or symbolic meanings is shared among a group. The 'process' dimension involves the way in which individuals and groups are attached to a place, with affect, cognition, and behavior as the three psychological aspects of the process. Whilst affect incorporates the emotional connection to a place; and the cognitive elements include memories, meanings, beliefs and knowledge of a place; behavior entails demonstrating 
attachment through actions such as proximity maintaining behaviors. The third dimension is the place itself which involves the physical aspects, and the social interaction that the place affords.

Places are important contexts for social relationships and it is to those relationships, not just to place, to which people are attached (Low \& Altman, 1992). Although both social and physical attachments influence the overall bond one has with a place, the social dimension may be stronger as a sense of place is socially constructed and develops through shared behavioral processes (Lewicka, 2011). A study by Hidalgo and Hernandez (2001) found that social attachment is greater than physical attachment and that a house/home is more significant in developing the affective bond than a neighborhood/city. In understanding attachment to third places (e.g. coffee shops) Rosenbaum et al. (2007) found emotional support to be important in facilitating the development of place attachment among customers.

According to Scannell and Gifford (2014), place attachment is similar to interpersonal attachment, as they provide individuals with a sense of safety and comfort. Individuals can have attachments to temporary places such as second homes (Stedman, 2006). Negative emotional consequences, such as homesickness, can arise if an individual changes their place of residence, but interchangeability processes can aid transition; such as seeing similarities between the old and new environments (Ryan \& Ogilvie, 2001). Additionally, research has found that individuals can form strong bonds to multiple places. Giuliani, Ferrara, and Barabotti (2003) found that air force personnel and their families had attachments to previous residences as well as their current residence. Generic place dependence (Stokols \& Shumaker, 1981), suggests that multiple place attachments can coexist together in a schema containing the knowledge and beliefs regarding the common features that make the places special. Given the regular need to smoke it is likely that smokers will be attached to multiple places. 
Our research contributes to understanding the processes of place attachment. Place attachment research has recently shifted to issues that we address. For instance, how memory, multiple simultaneous place attachment, and experience might contribute toward understanding place attachment (see Manzo \& Devine-Wright, 2014). Place attachment processes are emphasized through patterns of movement and places of rest such that smokers' everyday routines are integrated in a time-space lattice (Merleau-Ponty, 1962; Seamon, 1979). Thus, the habitual act of smoking inscribes the place with meaning. Place interaction, which contributes to the modes and intensity of the person-place bond, has been identified as a process for which places can be interpreted (Seamon, 2012), and relates to how one affectively attaches to place. Place interaction consists of the usual goings-on, including behaviors, in a place. One mode of place interaction is place ballet (an interaction between individual bodily routines that are grounded in place with the potential for the place to be significant for social exchanges; Jacobs, 1961). The place interaction process could consist of smoking with friends in a pub garden, or smoking while driving to and from work. These smoking sites could exemplify not only an interaction with the place but also the place identity process because the place becomes a significant part of the smoker's identity. For example, some smokers identify as social smokers who only smoke in the presence of others and at social events. Place is therefore a vital element in the decision to smoke. Such places could be viewed as safe havens, which are particularly relevant for marginalized groups such as smokers (Fried, 2000). Repeated enactment over time in such a place results in a functional connection and a dependence relation between smoker and place. This notion speaks to Scannell and Gifford's (2017) psychological benefits of place attachment which include memories, belonging, relaxation, personal growth and connection to nature. Further, studies show that place attachment can foster feelings of trust, well-being and security (e.g., Debenedetti, Oppewall, \& Arsel, 2014). Taken 
together these studies indicate the significance and importance of place attachment for psychological well-being.

Our research examines the processes and place dimensions of Scannell and Gifford's (2010) model. We focus on understanding the mosaic of places that smokers use, their characteristics; the reasons that the smoking sites are chosen; and their relevancy to the self-concept. In doing so, we advance place attachment literature regarding multiple place attachments and the processes of attachment to private or public places.

\section{Method}

A qualitative approach was employed and was anchored on 30 interviews with current smokers in and around one city in North Wales, UK. The research was conducted in 2014 and funded by a Research Grant awarded by the UK Academy of Marketing. A purposive sampling strategy of 30 participants was employed with the aim of obtaining rich data (Morse. 2000). The composition of the sample was diverse regarding gender, age, life stage, occupations and living accommodations. Over half (57\%) of the participants were female, the average age was 34 , and two participants lived alone. Most (77\%) were daily smokers, with the sample smoking an average of 12 cigarettes a day. Photo elicitation was adopted whereby participants were requested to come to the interview with photographs of places they associate with smoking. The photographs were used as stimuli in the interview and served as a rich source of data in tandem with the interview transcript. Visual methods are under-utilized in studies of place attachment (Stedman, Amsden, Beckley, \& Tidball, 2014), but have several advantages including the ability to: capture richer information; delve into often unconscious meanings of representations; and reduce differences in power, class or knowledge between the researcher and the participant (Van Auken, Frisvoll, \& 
Stewart, 2010). This method supports the view that images evoke deeper elements of human experiences than words alone (Harper, 2002).

Smokers were recruited by posting flyers on community and supermarket notice boards in the city, e-mailing all staff at the authors' workplace, and posting details of the study on a public community Facebook group. Ethical approval was granted prior to participant recruitment.. Individuals who expressed an interest in being interviewed were e-mailed an information sheet which included details of the research project as well as assurances of confidentiality and anonymity. The information sheet requested that participants take a number of photographs (between 5 and 8) of their smoking places prior to the interview. Interviews were undertaken either at a public place, or at the home of the smoker, and lasted on average 40 minutes. Participants were paid a $£ 10$ fee, and written consents were obtained for the use of all images. The interviews followed a loose structure starting with introductions, to an initial exploration of the participant's 'smoking journey'. Participants were then asked to describe the photos and were prompted to discuss why they had taken photos of those specific places; why those places were important to them, and who else used those places. To probe further meanings, participants were asked questions covering how those places represented them; their feelings about those places; their senses and experiences in those places, how they connected with those places, and the role of others in influencing the places that they smoked. To avoid priming the participants, words such as 'attachment' or 'bond' were not used. All interviews were recorded and transcribed verbatim.

The inductive nature of the research required ideas and themes to emerge from the data. Thus, open-ended, non-directive questions relating to places were asked. During the analysis, the data was coded based on themes emerging from the data, as opposed to using a pre-determined coding system (Denzin \& Lincoln, 1998). Interpretation of the data was assisted by using NVivo software 
(version 10), which supported the data analysis. A semantic approach to coding was employed as a way of exploring the meanings extracted from the participants' descriptions of places. Braun and Clarke's (2006), six phase approach was followed. Accordingly, each section of the data was coded into a number of 'nodes' (codes), and later reduced to three themes. The data was independently coded by a second researcher to ensure consistency.

\section{Results}

\subsection{Overview of smoking places}

The participants smoked in a number of public and private places varying from specific rooms within the home to broader public places such as beaches and mountains (see Table 1). Photo 1 was taken by a smoker who smoked predominantly in her car whereas in photo 2 , this female smoker smoked in her back garden but not inside the home. In photo 3, this male smoker smoked only in his kitchen.

Photo 1 (P5)

Photo 2 (P15) 


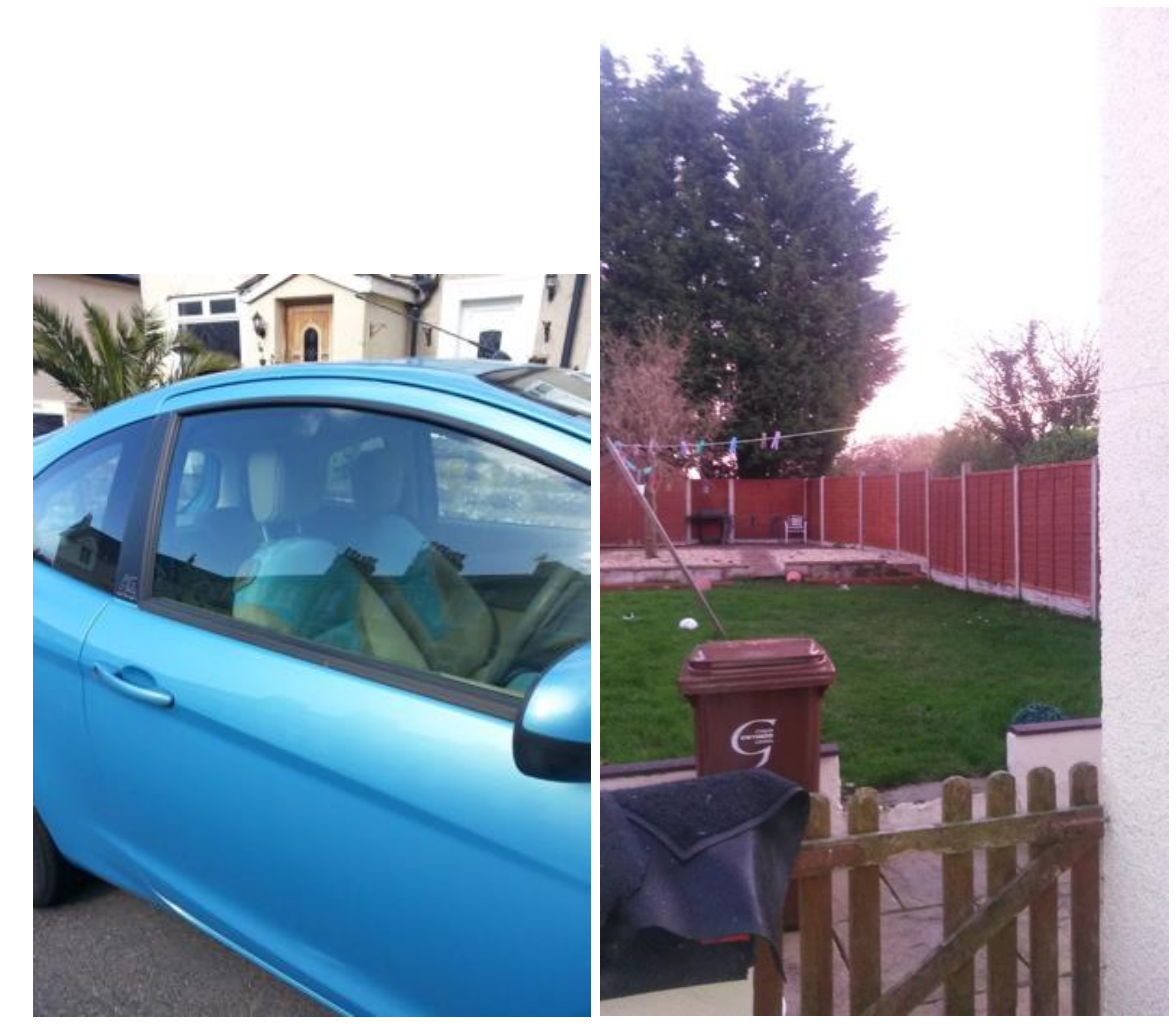

Photo 3 (P18)

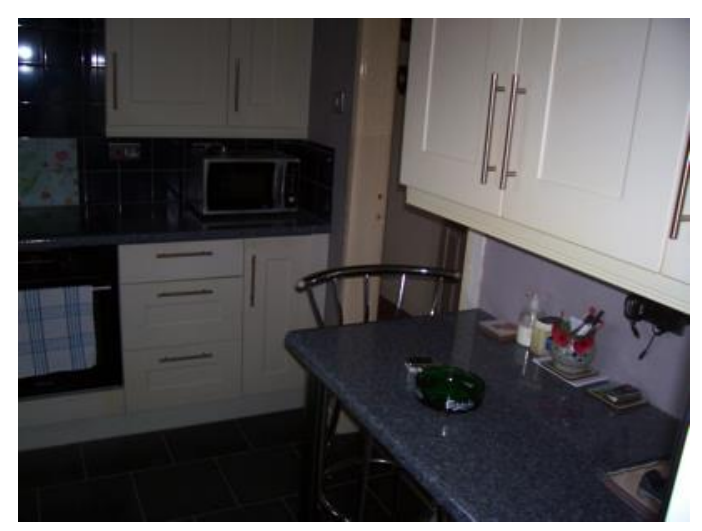

All participants routinely smoked in at least two places, although most had a preferred smoking place to which they formed an attachment. Many displayed multiple place attachments (e.g. P7 demonstrated attachment to a pub, her living room and a friend's house). The duration in the places was typically short (e.g. popping outside to smoke in one's back yard) but longer when 
connected with other smokers (e.g. at the pub). The strength of smokers' place attachment differed among places, for instance P18's kitchen was his favorite place to smoke, and he also enjoyed smoking at a nearby pier, but displayed little attachment to designated smoking areas at work.

The way in which participants defined their smoking places is important in terms of what made the places unique and the perceived boundaries of the places, particularly in light of the blurred distinction across public and private places. For instance, a remote hillside was referred to as a "private place" whilst a terrace within a shared home was considered a social hub. The images captured by participants illustrate how the smokers viewed their various places. For example, Photo 4 depicts an abstract territory whereas Photo 5 depicts a fixed territory within smoker's home. Three inter-related themes capture the processes by which smokers form attachments to smoking sites. Participant quotations and photos are used to illustrate the themes of seclusion and concealment; sociality; and control.

Photo 4 (P23)

Photo 5 (P16)

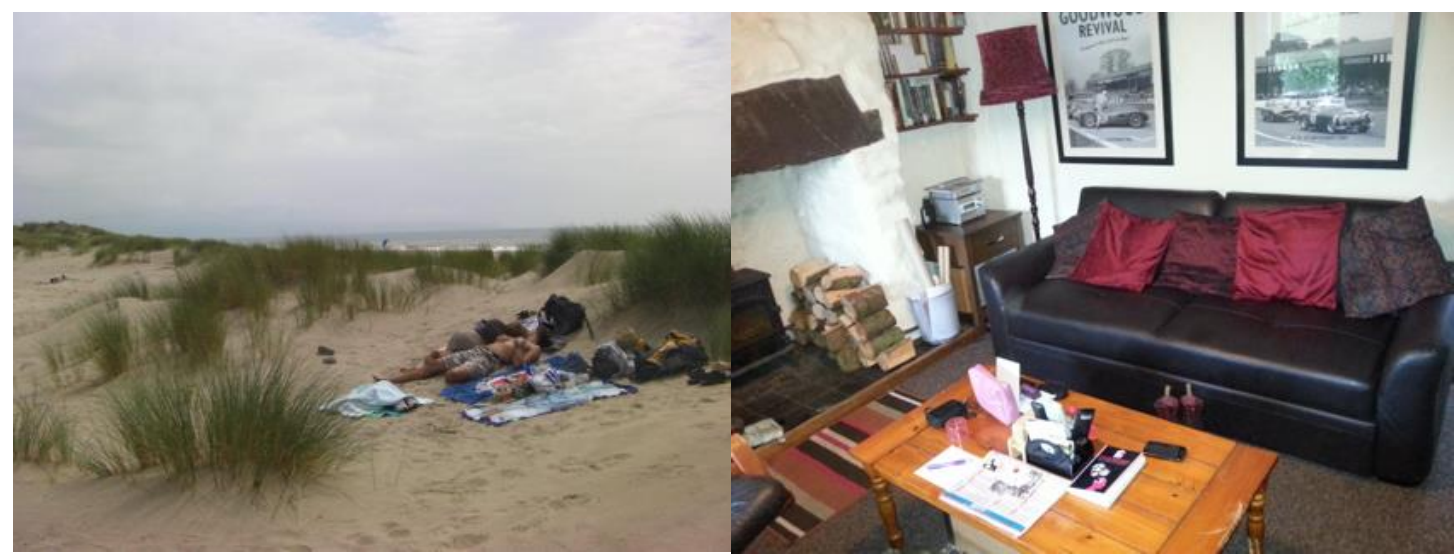

\subsection{Seclusion and concealment}




\subsubsection{Smoking in secluded private places due to fear of potential judgement}

Many smokers chose secluded places predominantly due to fear of potential judgment from others. The feelings of threat from others seeing their smoking behavior resulted in smokers moving to another (more secluded) place. These places became significant as the smoker was able to fulfil their goal of smoking without surveillance from others. Linkage can be made to the security and goal support functions of place attachment (Scannell \& Gifford, 2010), where smokers chose safe and comfortable places to enjoy smoking. Within the home the desire to conceal smoking was also evident due to the presence of others:

I can go on my own without nobody else there and it's just a way of relief for me, yeah, it's quiet, nobody else there, nobody can see me having a cigarette whilst at home anyway and that's where I like to go (P15).

Parents...are unaware that me and my husband smoke. We do tend to hide if we know they're coming (P2).

Smokers avoided negative reactions that might arise from others seeing their behavior. Smoking alone was thus a relief because it was free from disapproval from others, underscoring the importance of places as safe havens in line with Bowlby's (1982) psychological process underpinning attachment relationships:

Private, away from work... as soon as the door shuts I'm home, I'm in my own little haven, I'm in my own private, safe space. Pretty much the same in the car actually... yeah, peaceful, personal spaces where I'm on my own, I can make the conscious decision whether I smoke or not, and there's nobody there to criticize me for it (P18). 
The quote above also signifies that multiple places (home and car) can fulfil the same (safe haven) function. As such, smokers can form multiple attachments connected through the functional benefits (i.e. safety and freedom from disapproval) that these places provide; in line with the concept of generic place dependence (Stokols \& Shumaker, 1981).

\subsubsection{Concealed smoking in public places due to fear of social disapproval}

When smoking in public, the theme of seclusion and concealment was still present. In public the potential for disapproval is greater and social norms are important to consider in choosing smoking sites. The place interaction process (Seamon, 2012) is important here because smoking is not considered a normative behavior to perform in many public places. The co-presence of non-

smokers in the public place created the potential for distress. Smokers therefore paid significant attention to place definition regarding the socially constructed and negotiated place boundaries, taking into account the features and attributes that confer a distinctive identity of the place in their minds (Schneider, 1986). As a result, smokers tended to select hidden places that helped them conceal their behaviour:

These days, you do tend to feel more of a pariah. I've noticed that. I mean that's probably one of the other reasons why I do go to the car, because I don't like hanging around the university doors having a cigarette, because you don't see that many people doing it (P16). 
I hate smoking out in the open. I wouldn't just stand there like in the middle of the [public] lawn there and just start smoking because I just feel like people just look at me funny (P25).

\subsubsection{Benefits arising from seclusion in public places}

Seeking out a secluded place in public was often intertwined with enjoying smoking outside and related to appreciating nature and views; echoing Scannell and Gifford's (2017) view that choice of place yields a goal supportive benefit arising from a fit between the smoker's needs and the attributes associated with the place. The reasons for choosing secluded places differed across smokers, but a large proportion of participants associated smoking with quiet, peace, and time for the self (as illustrated in Photo 4). The routine of smoking in such places often involved rest and a time to be stationary that afforded stress-free self-reflection and place meaning making. For many smokers, outside public places could become private places that allowed them to alter their state of mind. The psychological and aesthetic benefits that could be gained from outdoor public places allowed the smoker to, for instance, become more relaxed and at ease with themselves (as a smoker):

I know that sounds awful, like getting to the top of Snowdonia and you're knackered and then you have a cigarette. But it does, like, sitting there looking at the view and having a cigarette...for me that's really enjoyable, and it does improve it. Improves the experience (P17). 
I've always associated smoking with creative thinking...I relax and it helps that process...the area is quite secluded, quite quiet...just smoking by myself and no-one else around. I think that's why I pick those spaces (P25). 
Photo 6 (P29)

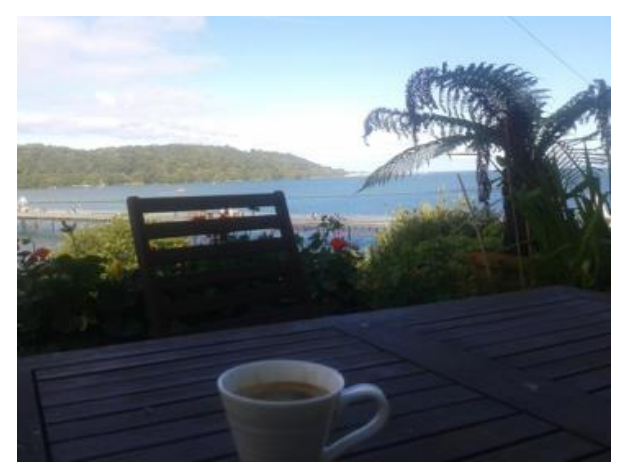

\subsection{Sociality}

\subsubsection{Collectivity and positive social experience}

Participants discussed multiple smoking places which were shared by other smokers, such as friends' homes and restaurant/bar smoking areas. The presence of other smokers facilitated a more relaxed smoking experience. Many smokers referred to a special social experience that often occurred in these places:

You go out and meet other smokers because you're forced to go to specific smoking places...so you get opportunities to chat to people that you would otherwise probably never get, and that is actually quite interesting (P14).

That's one of the things that I keep smoking for is because you actually go into those smoking rooms (in a club), it's very, very sociable (P23).

The above supports the work of Tan (2013) who found that smoking places are enabling a sense of well-being through sensoriality (relaxation, escaping from normality), and sociality (smoking places encouraging collective bonds and solidarity among smokers). For smokers 
seeking to fulfil belongingness or affiliation needs, smoking with others was central (see Photo 5), suggesting that the place experience became part of a wider social exchange process and incorporated relationships with others (Low \& Altman, 1992). These smokers were not seeking to smoke alone, but the reverse:

The pub places aren't private. They're really, really social places. Loads and loads of people there. But they're, like, not a certain type of people but they're out for a certain type of occasion that they're all out socializing and there are a lot of smokers out (P27).

Smokers who sought collectiveness did not perceive those places as private. For instance, when at home smoking in her back garden with a friend, P17 referred to it as a "social" place. In illustrating that sociality results in an attachment to the place, the female below referred to a balcony (a site often used for smoking) at her shared house:

The balcony is the only place everyone really uses. We have our morning cups of tea and our cigarettes there. We have our communal cups of tea. We play cards out there. It's pretty much just the place, the hub of the house (P27).

It's nice, I suppose it's like a group feeling of smokers (P24).

The togetherness that smokers valued in a group setting echo Tan's (2013) findings whereby segregated smoking and non-smoking sites offers opportunities for collective bonding among smokers, leading to social wellbeing. 
Photo 7 (P23)

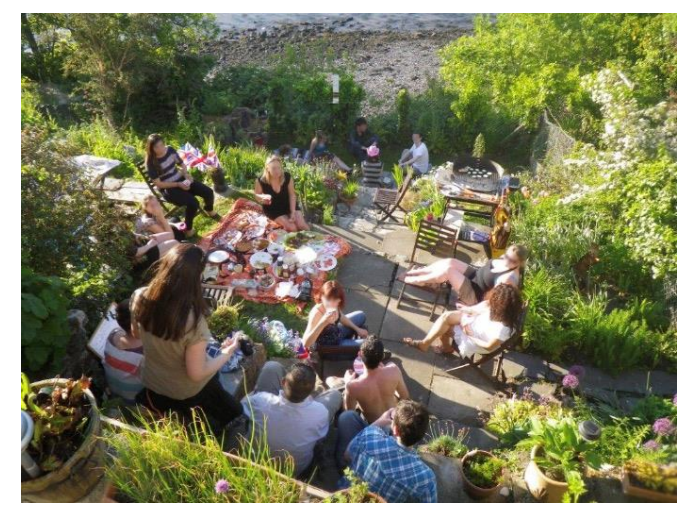

\subsubsection{Social smoking, memories, and identity}

Some places triggered positive memories for smokers and enabled them to reminisce about happy times; echoing Gustafson's (2001) work on place and meaning processes. Continuity, where places become connected to one's life path through social relations, builds memories that anchors attachment to the place. This male smoker reflected on smoking in his back garden, leading to a strong attachment with the place and his self-view as a smoker:

See the garden as smoking, then it's kind of okay, good and reminiscing moments where I've had a barbecue with friends or something like that and I think of all the good times I've had there. So perhaps the place in itself is also inducing me to smoke (P23).

An attachment with a smoking place often meant spending more time in that place as the place itself facilitated smoking; echoing the place interaction process (Seamon, 2012). This was particularly evident amongst the 'social smokers' as conversations flowed in the smoking place, described by another smoker (P23) as "magical...a very special moment." 
The places represented aspects of individuals' personality, with place cognitions relating to their self-concept (Hernandez et al., 2010). The notion of place identity was also apparent in participants' self-definitions relating to the place (Proshansky et al., 1983). For example, those who liked having friends smoke in their home emphasized their 'laid back' personality:

I only really smoke one thing and the house works great for that...it's a very chilled out place. People are happy to come round...And that, kind of at the moment, is part of who I am...it works, it's a cool balcony. For smoking it definitely is the best thing (P27).

I guess there are two bits [to smoking matching my personality]. Like, one is just the general social element with me, and they fit in perfectly with...it's the places where I socialize often and places where I really enjoy being with friends. And then the whole part about me, like, growing up and exploring and being away from home and stuff, they fit in with that as well...Or it's the space of, like, new friends that I've met who definitely form part of who I am, and then also, like, it's places around North Wales where I've chosen to be, like, because of beaches, because of the mountains and stuff, so it all ties in really (P17).

The above quotes also emphasize the linkage between place attachment and interpersonal attachment, suggesting a hierarchical view of how places fit together in a more inclusive schema, each associated with the same benefits, concurring with our earlier discussion on generic place dependence. 


\subsection{Control}

\subsubsection{Place redefinition and rules in private places}

Many participants did not smoke in the home as they didn't like the smell of tobacco smoke on clothes and furnishings (Phillips et al., 2007). Another reason was not wanting to inflict tobacco smoke on non-smokers corroborating Poland's (2000) view that smokers are becoming 'considerate'. Many had made changes as a result of the introduction of smoking restrictions in public places. Thus, the home as a smoking site has undergone a process of place redefinition. One reason driving this change was attributable to increased knowledge and acceptance of the dangers associated with SHS:

I used to but since...I think it's since the ban came in.... I thought I'm sick of the smell of cigarettes and it's not fair on the kids...So I said I'm not doing it anymore, I'm not doing it in the house (P15).

As a way of controlling their space, smokers used self-imposed or consensually agreed-upon rules of acceptable areas to smoke within the home. In some circumstances, smokers were not empowered to contest views put forward by important others in the household, leading to alternative smoking sites being imposed by others. Although Stedman (2002, p. 577) pointed out that individuals are "willing to fight for places that are central to our identities", in the case of smokers, the fact that marking the area with smoke might be unhealthy for others weakened smokers' willingness to fight for previously attached sites: 
As a house we brought in the rule that we just smoke outside or at least at the back door (P22).

It's the only place I'm allowed to smoke indoors, so it is important because of that...in the Summer it's a lovely room because we get all the sun in the afternoon and evening, we call it the sunroom and it really is...lovely...it's got all my things in it (P3).

\subsubsection{Territorial marking and defense in public and private places}

Territory is linked to the behavioral dimension of Scannell and Gifford (2010)'s tripartite place attachment model. While the behavioral dimension consists of both proximity-maintaining behaviors and place reconstruction, territorial behaviors require an element of control and can be expressed through actions such as personalization, and defending the place (Vinsel, Brown, Altman, \& Foss, 1980; Gifford, 1987). Within the home the most likely actions enacted by smokers were personalization and defending:

In the house I smoke there because that's the place I like to sit....I have a smoking drawer...full of smoking crap (P7).

So, my home is very much, I say my own space, our own space, and I'll defend that.

Quite jokingly, Englishman, home is his castle. I view that property as my own space.

Nobody interferes. If I wish to smoke within there, don't come near there (P18).

Most participants smoked in their cars, which represented their right to freedom. Cars could also be used as a safe haven to retreat away from perceived surveillance. Property ownership was important in providing smokers with a sense of their right to choose how to use their car: 
The car is the only place that is my own so the rules within that space are entirely of my making (P11).

Obviously my car is mine, and, you know, what I do in there is, you know, my business really. You know, I do feel quite possessive obviously about my car (P8).

The interviews also suggest that people can form a sense of ownership and control over places that are not owned legally. For instance, participants who regularly used a pub felt that it became 'their' pub thus place attachment is intertwined with territoriality over the place. The attachment to these particular places is formed through repeated connections between the place and smoking, and can form as a result of one's own interaction with a place or with the interaction between the place and others:

You pick these spots and this is where you'll be smoking for a long time. So I find myself, even though it's a 24 hour library, that entrance is closed, so sometimes if I'm smoking there, I go to the main entrance walking around. I've grown an attachment to it because it's like 'your area'. It's like parking spots some people have (P25).

So both of us went out of the building, or to the cafeteria and out of the cafeteria, to the smoker zones.....because it was like our place, you know, between us, to have like our space, to feel relaxed (P29).

A recurring theme is how smoking places become re-signified, such as a café being termed 'ours' or a smoking area at work being considered private and personal, resulting in stronger bonds with the places. This concurs with Gustafson's (2001) view that physical place does not induce attachment but that place gains significance through the meanings people attribute to it. These 
places are often away from home and offer opportunities for personal growth, experience, and freedom.

\section{Discussion}

Over 1.1 billion people smoked tobacco worldwide in 2015 (World Health Organization, 2018). Smoking has declined in recent years, and restrictions on smoking in public places have increased across a number of countries with the aim of improving and protecting health for all. However, the consequences of such restrictions on smokers' relationships with public and private places, and on their psychological and social well-being, are unclear. The large number of current smokers thus constitute an important societal group to study in relation to place, particularly in light of calls to legislate public and private places even further (The Independent, 2017; The Telegraph, 2017).

This study explored the psychological processes of smokers' place attachment across multiple public and private places. Starting with a behavior instead of a place allowed us to uncover the multitude of reasons as to why a smoking site was chosen, and how smokers formed an attachment with the place. Three themes captured the processes by which smokers form attachments to smoking places, namely: seclusion and concealment; sociality; and control.

The extent to which the themes applied to smokers varied across the diverse places (see Table 1). Both the 'sociality' and 'seclusion and concealment' themes were jointly identified for each smoker across a quarter of our sample. For example, P10 sought seclusion in one place (back garden) but collectivity in another (the pub and friend's house), suggesting that these smokers do not have the same requirements and cognitive processes toward each of the places. Of the 
remaining three-quarters of the sample who demonstrated an attachment to place, the data revealed why the multiple places were chosen, relating consistently to one theme (e.g. P18 smoked in his car and kitchen to be secluded from others). Similar benefits (e.g. a positive social experience with fellow smokers) were sought in a range of places (e.g. friend's house, pub, designated areas at work). However, in some instances some smokers were attached to the same type of place (e.g., a back garden) but for very different reasons (P2 sought seclusion and rest in her garden, whilst P17 associated her garden with social gatherings with friends).

One recurring theme is that places can be re-signified in the minds of smokers, resulting in place attachment (e.g. a smoking area outside a cafeteria becoming a favorite place). Public places, such as outdoor smoking areas, are social, collective, shared places that are co-created by these smokers. The attachments formed in such 'third places' demonstrate that a sense of 'homeyness' can exist outside domestic settings (Debenedetti et al., 2014), as individuals are able to seek companionship and emotional support through their routine patronage of the place (Rosenbaum et al., 2007). However, smoking regulations and norms in public places are constantly negotiated between smokers and non-smokers, sometimes leading to perceived tension among the inhabitants of the place. This finding is in line with Dixon et al.'s (2006) research on street drinking, which identified the perceived moral integrity of shared public places and the ideological tension between freedom and social control in public places. Overarching insights suggest that the private/public place distinction is blurred for smokers, as they can view the home as a social, public place when with other smokers. Yet, some outside spots can be re-signified as their own private site for smoking.

Smokers' attachments with places are grounded in their daily routine or habit of smoking, but the relationship with the place builds over time although it is subject to constant shaping. Indeed, 
legislations around smoking and the increased awareness of secondhand smoke has changed the meaning of the home as a smoking place. Moreover, proximity-maintaining behaviors (e.g. frequenting a pub regularly) is important for maintaining the bond. The above observations confirm the importance of the place interaction process within place attachment (Seamon, 2012).

As discussed above, our findings are relevant to environmental psychologists as smokers still represent a sizable proportion of the adult population. Further, our themes may apply to other contexts (e.g., hoarding and drinking alcohol). For example, hoarders may have a strong desire to conceal their behavior from others. In the case of drinking alcohol in public, rules about the legality of this action might lead to concealment; yet, drinking alcohol can often be considered a social occasion. Our approach, starting from a behavior rather than a place, might also provide impetus to other researchers in the place attachment field and lead to new empirical and theoretical insights.

Public smoking restrictions leading to denormalization of smoking has both positive and negative consequences for smokers. On the one hand, some smokers struggle with their identity as a smoker and therefore want to conceal this aspect of the self. Such behavior suggests that smoking negatively impacts well-being. On the other hand, smokers enjoy interacting with other smokers in places that legitimize smoking (e.g., smoker zones) and, for some, these places reinforce the desire to smoke. On the whole, smokers become attached to places that allow them to be who they are (i.e. smokers). The bond between smoker and place is reinforced as there are few places that smokers feel comfortable smoking. As such, there is a conundrum for regulators and policy makers, because further regulation of smoking in private places (such as cars or homes) may disrupt existing place attachments, and lead to defensive reactions and negative well-being. Our findings show that smokers are aware of the need to be considerate, and have adjusted their behavior regarding the places where they smoke. But if smokers feel that regulations step too far 
into their "own" territory, they may react more forcefully to defend the few places that offer them a safe haven to enjoy a behavior that is important to them.

Despite a reasonable number of interviews, limitations of this research could include potential volunteer bias which may have arisen due to the recruitment strategy used, and the potential social desirability bias in participants' accounts of their 'considerate' smoking behavior. Continuing research on the smoker-place relationship is vital in light of the potential of further regulations on smoking in private (and public) areas.

\section{Conclusion}

Our findings demonstrate that smokers form multiple attachments to the places that they smoke. For most smokers, the undesirable view of smoking in society leads to the need for seclusion and concealment. The resultant smoking places are chosen to fulfil the desire to enjoy smoking while maintaining a positive self-concept. Some public places were re-signified into private places in the minds of smokers, enhancing their bond with the place. Overall, our findings

provide insights into the processes of place attachment in a behavioral context yet unexplored in this literature.

\section{Acknowledgments}

The authors wish to thank Professor Edward Shiu, the reviewers and the Associate Editor for their valuable comments on earlier drafts. The authors would also like to thank the participants for taking part, and the Academy of Marketing for funding the study. 


\section{References}

Bell, K., Salmon, A., Bowers, M., Bell, J., \& McCullough, L. (2010). Smoking, stigma and tobacco 'denormalization': Further reflections on the use of stigma as a public health tool. A commentary on Social Science \& Medicine's stigma, prejudice, discrimination and health special issue (67:3). Social Science \& Medicine, 70, 795-799. https://doi.org/10.1016/j.socscimed.2009.09.060.

Bowlby, J. (1982). Attachment and loss: Vol. 1. Attachment ( $2^{\text {nd }}$ ed.). New York: Basic Books. Braun, V., \& Clarke, V. (2006). Using thematic analysis in psychology. Qualitative Research in Psychology, 3, 77-101.

Brown, B., \& Perkins, D. (1992). Disruptions in place attachment. In I. Altman \& S. Low (Eds.), Place Attachment: Human Behavior and Environment (pp. 279-304). New York, NY: Plenum.

Carr, S., Francis, M., Rivlin, L. G., \& Stone, A. M. (1992). Public Space. Cambridge University Press.

Debenedetti, A., Oppewal, H., \& Arsel, Z. (2014). Place attachment in commercial settings: A gift economy perspective. Journal of Consumer Research, 40, 904-923. http://dx.doi.org/10.1086/673469. 
Denzin, N., \& Lincoln, Y. (1998). Collecting and Interpreting Qualitative Materials. Thousand Oaks, CA: Sage.

Dixon, J., Levine, M., \& McAuley, R. (2006). Locating impropriety: Street drinking, moral order, and the ideological dilemma of public space. Political Psychology, 27, 187-206. http://dx.doi.org/10.1111/j.1467-9221.2006.00002.x.

Feldman, R. M. (1990). Settlement-identity: Psychological bonds with home places in a mobile society. Environment and behavior, 22(2), 183-229.

https://doi.org/10.1177/0013916590222002

Ferketich, A. H., Lugo, A., Le Vecchia, C., Fernandez, E., Boffetta, P., Clancy, L., \& Gallus, S. (2014). Relation between national-level tobacco control policies and individual-level voluntary home smoking bans in Europe. Tobacco Control, 25, 60-65.

http://dx.doi.org/10.1136/tobaccocontrol-2014-051819.

Fried, M. (2000). Continuities and discontinuities of place. Journal of Environmental Psychology, 20, 193-205.

Gifford, R. (1987). Environmental psychology: principles and practice. Boston: Allyn and Bacon.

Giuliani, M. V., Ferrara, F., \& Barabotti, S. (2003). One attachment or more? In G. Moser, E.

Pol, Y. Bernard, M. Bonnes, J. A. Corraliza, M. V. Giuliani (Eds.), People, Places and Sustainability (pp. 111-122). Hogrefe \& Huber Publishers: Toronto.

Goffman, E. (2008). Behavior in public places. Simon and Schuster.

Gustafson, P. (2001). Meanings of place: Everyday experience and theoretical conceptualizations. Journal of Environmental Psychology, 21(1), 5-16.

http://dx.doi.org/10.1006/jevp.2000.0185 
Gross, M. J., \& Brown, G. (2008). An empirical structural model of tourists and places:

Progressing involvement and place attachment into tourism. Tourism Management, 29, 1141-

1151. http://dx.doi.org/10.1016/j.tourman.2008.02.009.

Harper, D. (2002). Talking about pictures: A case for photo elicitation. Visual Studies, 17, 13-26. http://dx.doi.org/10.1080/14725860220137345.

Hidalgo, M. C., \& Hernandez, B. (2001). Place attachment: Conceptual and empirical questions. Journal of Environmental Psychology, 21, 273-281. http://dx.doi.org/10.1006/jevp.2001.0221.

Hernández, B., Martín, A. M., Ruiz, C., \& del Carmen Hidalgo, M. (2010). The role of place identity and place attachment in breaking environmental protection laws. Journal of Environmental Psychology, 30(3), 281-288. https://doi.org/10.1016/j.jenvp.2010.01.009.

Housing and Urban Development Department (2016). Instituting smoke-free public housing. Retrieved from: $\quad$ https://www.federalregister.gov/documents/2016/12/05/201628986/instituting-smoke-free-public-housing.

Jacobs, J. (1961). The death and life of great American cities. New York: Vintage.

Kalandides, A. (2011). The problem with spatial identity: Revisiting the "sense of place." Journal of Place Management and Development, 4, 28-39.

http://dx.doi.org/10.1108/17538331111117142.

Knez, I., Butler, A., Sang, Å. O., Ångman, E., Sarlöv-Herlin, I., \& Åkerskog, A. (2018). Before and after a natural disaster: Disruption in emotion component of place-identity and wellbeing. Journal of Environmental Psychology, 55, 11-17. https://doi.org/10.1016/j.jenvp.2017.11.002. Lewicka, M. (2011). Place attachment: How far have we come in the last 40 years? Journal of Environmental Psychology, 31, 207-230. http://dx.doi.org/10.1016/j.jenvp.2010.10.001. 
Low, S., \& Altman, I. (1992). Place Attachment: A Conceptual Inquiry. In I. Altman \& S. Low (Eds.), Place Attachment: Human Behavior and Environment (pp. 1-12). New York, NY: Plenum.

Manzo, L. C., \& Devine-Wright, P. (2014). Introduction. In L. C. Manzo \& P. Devine-Wright (Eds.), Place attachment: Advances in theory, methods and applications (pp. 1-7). London: Routledge.

Martinez-Sanchez, J. M., Fernandez, E., \& Gallus, S. (2014). Do smoke-free policies in work and public places increase smoking in private venues? Tobacco Control, 23, 204-207. http://dx.doi.org/10.1136/tobaccocontrol-2012-050877.

Mbulo, L., Pallipudi, K. M., Andes, L., Morton, J., Bashir, R., Fouad, H., Ramanandraibe, N., Caixeta, R., Dias, R. C., Wijnhoven, T. M., Kashiwabara, M., Sinha, D. N., \& $\underline{\text { Tursan }}$ d'Espaignet E. (2016). Secondhand smoke exposure at home among one billion children in 21 countries: findings from the Global Adult Tobacco Survey (GATS). Tobacco Control 25, e95e100. http://dx.doi.org/10.1136/tobaccocontrol-2015-052693.

Merleau-Ponty, M. (1962). The phenomenology of perception. New York: Humanities Press. Morse, J. M. (2000). Determining sample size. Qualitative Health Research, 10, 3-5. http://dx.doi.org/10.1177/104973200129118183.

Passey, M. E., Longman, J. M., Robinson, J., Wiggers, A., \& Jones, L. (2016). Smoke-free homes: what are the barriers, motivators and enablers? A qualitative systematic review and thematic synthesis. BMJ Open, 6, e010260. http://dx.doi.org/10.1136/bmjopen-2015-010260. Phillips, R., Amos, A., Ritchie, D., Cunnigham-Burley, S., \& Martin, C. (2007). Smoking in the home after the smoke-free legislation in Scotland: qualitative study. British Medical Journal, 335, 553-557. http://dx.doi.org/10.1136/bmj.39301.497593.55. 
Poland, B. D. (2000). The 'considerate' smoker in public space: The micro-politics and political economy of 'doing the right thing'. Health \& Place, 6, 1-14. https://doi.org/10.1016/S1353$\underline{8292(99) 00025-8 .}$

Proshansky, H. M., Fabian, A. K., \& Kaminoff, R. (1983). Place-identity: Physical world socialization of the self. Journal of Environmental Psychology, 3, 57-83.

http://dx.doi.org/10.1016/S0272-4944(83)80021-8.

Raymond, C. M., Brown, G., \& Weber, D. (2010). The measurement of place attachment: Personal, community, and environmental connections. Journal of environmental psychology, 30(4), 422-434. https://doi.org/10.1016/j.jenvp.2010.08.002.

Rishbeth, C., \& Powell, M. (2013). Place attachment and memory: Landscapes of belonging as experienced post-migration. Landscape Research, 38(2), 160-178. https://doi.org/10.1080/01426397.2011.642344.

Ritchie, D., Amos, A. \& Martin, C. (2010a), “But it just has that sort of feel about it, a leper”Stigma, smoke-free legislation and public health. Nicotine \& Tobacco Research, 12, 622-629. https://doi.org/10.1093/ntr/ntq058.

Ritchie, D., Amos, A. \& Martin, C. (2010b). Public places after smoke-free-A qualitative exploration of the changes in smoking behaviour. Health \& Place, 16, 461-469. http://dx.doi.org/10.1016/j.healthplace.2009.12.003.

Rosenbaum, M. S., Ward, J., Walker, B. A., \& Ostrom, L. (2007). A cup of coffee with a dash of love: An investigation of commercial social support and third-place attachment. Journal of Service Research, 10, 43-59. http://dx.doi.org/10.1177/1094670507303011. 
Ryan, M. M., \& Ogilvie, M. (2001). Examining the effects of environmental interchangeability with overseas students: A cross cultural comparison. Asia Pacific Journal of Marketing and Logistics, 13(3), 63-74. http://dx.doi.org/10.1108/13555850110764838

Scannell, L. \& Gifford, R. (2010). Defining place attachment: A tripartite organizing framework. Journal of Environmental Psychology, 30, 1-10. http://dx.doi.org/10.1016/j.jenvp.2009.09.006.

Scannell, L. \& Gifford, R. (2014). Comparing the theories of interpersonal and place attachment. In L. C. Manzo \& P. Devine-Wright (Eds.), Place attachment: Advances in theory, methods and ppplications (pp. 23-36). London: Routledge

Scannell, L. \& Gifford, R. (2017). The experienced psychological benefits of place attachment. Journal of Environmental Psychology, 51, 256-269. http://dx.doi.org/10.1016/j.jenvp.2017.04.001.

Schneider, G. (1986). Psychological identity of and identification with urban neibourhoods. In D Frick (ed.). The quality of urban life (pp. 203-218). Berlin: Walter de Gruter.

Seamon, D. (1979). A geography of the lifeworld. New York: St Martin's.

Seamon, D. (2012). Place, place identity, and phenomenology. In H. Casakin, \& F. Bernardo (eds.), The role of place identity in the perception, understanding, and design of the built environment (pp. 3-21). London: Bentham Science Publishers.

Sheller, M. \& Urry, J. (2003). Mobile transformations of 'Public' and 'Private' life. Theory, Culture \& Society, 20, 107-125. http://dx.doi.org/10.1177/02632764030203007.

Sim, A., Fazel, M., Bowes, L., \& Gardner, F. (2018). Pathways linking war and displacement to parenting and child adjustment: A qualitative study with Syrian refugees in Lebanon. Social Science \& Medicine, 200, 19-26. http://dx.doi.org/10.1016/j.socscimed.2018.01.009. 
Smith, N., \& Low, S. (2006). The imperative of public space. In N. Low \& S. Altman (Eds.), The politics of public space (pp.3-4). London: Routledge.

Stedman, R. C. (2002). Toward a social psychology of place: Predicting behavior from placebased cognitions, attitude, and identity. Environment and Behavior, 34, 561-581. http://dx.doi.org/10.1177/0013916502034005001.

Stedman, R. C. (2006). Understanding place attachment among second home owners. American Behavioral Scientist, 50, 187-205. http://dx.doi.org/10.1177/0002764206290633.

Stedman, R. C., Amsden, B. L., Beckley, T. M., \& Tidball, K. G. (2014). Photo-based methods for understanding place meanings as foundations of attachment. In L. C. Manzo \& P. DevineWright (Eds.), Place attachment: advances in theory, methods and applications (pp.112-124). London: Routledge.

Stokols, D., \& Shumaker, S. A. (1981). People in places: A transactional view of settings. In J. Harvey (ed.), Cognition, social behaviour, and the environment (pp. 441-488). Hillsdale, NJ: Erlbaum.

Strzelecka, M., Boley, B. B., \& Woosnam, K. M. (2017). Place attachment and empowerment: Do residents need to be attached to be empowered?. Annals of Tourism Research, 66, 61-73. https://doi.org/10.1016/j.annals.2017.06.002.

Tan, Q. H. (2013). Smoking spaces as enabling spaces of wellbeing. Health \& Place, 24,173-182. http://dx.doi.org/10.1016/j.healthplace.2013.08.003.

The Independent. (2017, June 29). UK Smoking ban at 10: Eight things that have changed since cigarettes prohibited in public a decade ago. Retrieved from:

https://www.independent.co.uk/life-style/health-and-families/health-news/smoking-ban-public10-years-ago-eight-changes-health-hospitals-pubs-teenagers-e-cigarettes-a 7813696.html. 
The Telegraph (2017, May 8) Council house residents could be banned from smoking in their homes. Retrieved from: https://www.telegraph.co.uk/news/2017/05/08/council-house-residentscould-banned-smoking-homes/

Tuan, Y. F. (1977). Space and place: The perspective of experience. U of Minnesota Press.

Tuan, Y. F. (1990) Topophilia: A study of environmental perceptions, attitudes, and values. Columbia University Press.

Van Auken, P. M., Frisvoll, S. J., \& Stewart, S. I. (2010). Visualising community: using participant-driven photo-elicitation for research and application. Local environment, 15(4), 373388. http://dx.doi.org/10.1080/13549831003677670.

Vinsel, A., Brown, B. B., Altman, I., \& Foss, C. (1980). Privacy regulation, territorial displays, and effectiveness of individual functioning. Journal of Personality and Social Psychology, 39(6), 1104. http://dx.doi.org/10.1037/h0077718.

World Health Organization. (2018, October 4). Prevalence of tobacco smoking. Retrieved from: http://www.who.int/gho/tobacco/use/en/

Williams, D. R., \& Vaske, J. J. (2003). The measurement of place attachment: Validity and generalizability of a psychometric approach. Forest Science, 49, 830-840. https://doi.org/10.1093/forestscience/49.6.830. 


\begin{tabular}{|c|c|c|c|c|c|c|c|c|c|c|c|}
\hline Code & Gender & Age & $\begin{array}{l}\text { Number } \\
\text { of } \\
\text { children in } \\
\text { household }\end{array}$ & $\begin{array}{l}\text { Marital } \\
\text { status }\end{array}$ & $\begin{array}{l}\text { Residential } \\
\text { status }\end{array}$ & $\begin{array}{l}\text { Number } \\
\text { of other } \\
\text { people in } \\
\text { household }\end{array}$ & $\begin{array}{l}\text { Daily, } \\
\text { weekly, } \\
\text { or } \\
\text { monthly } \\
\text { smoker }\end{array}$ & $\begin{array}{l}\text { Number } \\
\text { of } \\
\text { cigarettes } \\
\text { each } \\
\text { day/week/ } \\
\text { month }\end{array}$ & $\begin{array}{l}\text { Smoking } \\
\text { partner? }\end{array}$ & Smoking places & $\begin{array}{l}\text { Attachment } \\
\text { Theme(s) }\end{array}$ \\
\hline $\mathrm{P} 1$ & Female & 36 & 0 & Single & Rent & 4 & Daily & 7 & yes & $\begin{array}{l}\text { Bedroom, back } \\
\text { yard, coffee shop } \\
\text { (outside), } \\
\text { apartment in } \\
\text { home country }\end{array}$ & $\begin{array}{l}\text { Seclusion and } \\
\text { concealment }\end{array}$ \\
\hline $\mathrm{P} 2$ & Female & 28 & 0 & Married & Own home & 1 & Daily & 8 & yes & $\begin{array}{l}\text { Car, back garden, } \\
\text { smoking areas } \\
\text { outside pubs, } \\
\text { DSPW. }\end{array}$ & $\begin{array}{l}\text { S\&C, sociality, } \\
\text { control }\end{array}$ \\
\hline P3 & Female & 63 & 0 & Married & Own home & 1 & Daily & 15 & no & $\begin{array}{l}\text { Back porch at } \\
\text { home, DSPW. }\end{array}$ & Control \\
\hline $\mathrm{P} 4 *$ & Male & 32 & 0 & $\begin{array}{l}\text { Co- } \\
\text { habiting }\end{array}$ & Rent & 2 & Daily & 5 & no & $\begin{array}{l}\text { Back yard, } \\
\text { DSPW. }\end{array}$ & \\
\hline P5 & Female & 24 & 0 & $\begin{array}{l}\text { Co- } \\
\text { habiting }\end{array}$ & Rent & 1 & Daily & 10 & no & $\begin{array}{l}\text { Back yard at } \\
\text { home, car, } \\
\text { DSPW, mother's } \\
\text { back garden }\end{array}$ & S\&C, sociality \\
\hline P6 & Male & 54 & 0 & Married & Own home & 1 & Daily & 7 & no & $\begin{array}{l}\text { Work, nearby } \\
\text { mountain, beach, } \\
\text { back garden, car }\end{array}$ & $\mathrm{S} \& \mathrm{C}$ \\
\hline P7 & Female & 31 & 0 & Widowed & Rent & 0 & Daily & 10 & no & $\begin{array}{l}\text { Home-living } \\
\text { room, friend's } \\
\text { homes, pub. }\end{array}$ & $\begin{array}{l}\text { Sociality, S\&C, } \\
\text { control }\end{array}$ \\
\hline P8 & Female & 26 & 0 & Single & Rent & 5 & Daily & 10 & yes & $\begin{array}{l}\text { Garden, car, } \\
\text { DSPW, friend's } \\
\text { house, pub. }\end{array}$ & $\begin{array}{l}\text { Sociality, } \\
\text { control }\end{array}$ \\
\hline P9 & Female & 33 & 0 & Single & Own home & 0 & Weekly & 35 & yes & $\begin{array}{l}\text { Pub, friend's } \\
\text { houses, back door } \\
\text { at home }\end{array}$ & Sociality \\
\hline P10 & Female & 26 & 1 & Married & Rent & 2 & Daily & 20 & yes & $\begin{array}{l}\text { DSPW, car, back } \\
\text { garden, parent's } \\
\text { garden, high } \\
\text { street, pub }\end{array}$ & Sociality, S\&C \\
\hline P11 & Male & 40 & 0 & Single & $\begin{array}{l}\text { Living with } \\
\text { a friend } \\
\text { temporarily }\end{array}$ & 2 & Daily & 50 & no & DSPW, car & $\mathrm{S} \& \mathrm{C}$, control \\
\hline P12 & Male & 21 & 1 & Single & $\begin{array}{l}\text { Living with } \\
\text { parents }\end{array}$ & 4 & Daily & 13 & no & $\begin{array}{l}\text { Garage, friend's } \\
\text { house, pub, out } \\
\text { for walks, DSPW }\end{array}$ & Sociality \\
\hline $\mathrm{P} 13 *$ & Female & 51 & 0 & Single & Rent & 1 & Daily & 5 & no & $\begin{array}{l}\text { Home -kitchen, } \\
\text { designated } \\
\text { smoking area at } \\
\text { university, outside } \\
\text { cafes and pubs }\end{array}$ & \\
\hline P14 & Male & 45 & 0 & Married & Own home & 1 & Weekly & 18 & no & DSPW, pub & Sociality \\
\hline
\end{tabular}




\begin{tabular}{|c|c|c|c|c|c|c|c|c|c|c|c|}
\hline P15 & Female & 36 & 2 & Single & Own home & 3 & Daily & 2 & no & $\begin{array}{l}\text { Back yard, } \\
\text { DSPW, pub }\end{array}$ & Control, S\&C \\
\hline P16 & Female & 43 & 2 & $\begin{array}{l}\text { Co- } \\
\text { habiting }\end{array}$ & Rent & 4 & Daily & 5 & yes & Car, living room & $\mathrm{S} \& \mathrm{C}$, control \\
\hline P17 & Female & 25 & 0 & $\begin{array}{l}\text { Co- } \\
\text { habiting }\end{array}$ & Rent & 1 & Monthly & 8 & no & $\begin{array}{l}\text { Garden, friend's } \\
\text { balcony, pub, } \\
\text { beach, mountains }\end{array}$ & $\begin{array}{l}\text { Control, } \\
\text { sociality, S\&C }\end{array}$ \\
\hline P18 & Male & 50 & 0 & Married & Own home & 1 & Daily & 25 & yes & $\begin{array}{l}\text { Car, kitchen, } \\
\text { DSPW, garden, } \\
\text { pier }\end{array}$ & $\mathrm{S} \& \mathrm{C}$, control \\
\hline P19 & Male & 44 & 0 & Separated & Own home & 1 & Weekly & 40 & no & $\begin{array}{l}\text { Back yard, } \\
\text { DSPW, street }\end{array}$ & $\mathrm{S} \& \mathrm{C}$ \\
\hline P20* & Male & 28 & 0 & $\begin{array}{l}\text { Co- } \\
\text { habiting }\end{array}$ & Rent & 1 & Daily & 4 & yes & $\begin{array}{l}\text { Back yard, } \\
\text { designated spaces } \\
\text { at university, } \\
\text { pub/restaurant }\end{array}$ & \\
\hline $\mathrm{P} 21^{*}$ & Female & 47 & 0 & Married & Own home & 5 & Daily & 8 & yes & $\begin{array}{l}\text { Bedroom, kitchen, } \\
\text { living room, } \\
\text { DSPW, out in } \\
\text { public. }\end{array}$ & \\
\hline $\mathrm{P} 22$ & Female & 30 & 0 & $\begin{array}{l}\text { Co- } \\
\text { habiting }\end{array}$ & Rent & 1 & Daily & 3 & yes & $\begin{array}{l}\text { Car, back yard, } \\
\text { pub, fields, near } \\
\text { river }\end{array}$ & S\&C, sociality \\
\hline $\mathrm{P} 23$ & Male & 31 & 0 & $\begin{array}{l}\text { Co- } \\
\text { habiting }\end{array}$ & Shared & 2 & Weekly & 20 & yes & $\begin{array}{l}\text { Terrace, garden, } \\
\text { beach, pub, } \\
\text { nightclub }\end{array}$ & $\begin{array}{l}\text { Control, } \\
\text { sociality }\end{array}$ \\
\hline P24 & Male & 24 & 0 & $\begin{array}{l}\text { Co- } \\
\text { habiting }\end{array}$ & Rent & 2 & Daily & 14 & no & $\begin{array}{l}\text { Back door, } \\
\text { kitchen, bedroom, } \\
\text { DSPW, parent's } \\
\text { house }\end{array}$ & Sociality \\
\hline $\mathrm{P} 25$ & Male & 22 & 0 & Single & Shared & 2 & Daily & 26 & no & $\begin{array}{l}\text { Outside library, } \\
\text { accommodation } \\
\text { car park, friend's } \\
\text { house, pub. }\end{array}$ & Sociality, S\&C \\
\hline P26 & Male & 23 & 2 & Single & Rent & 3 & Daily & 25 & yes & $\begin{array}{l}\text { Smoking areas at } \\
\text { college, pub, } \\
\text { street, kitchen, } \\
\text { back door, } \\
\text { bedroom, friend's } \\
\text { houses }\end{array}$ & $\begin{array}{l}\text { Sociality, } \\
\text { control }\end{array}$ \\
\hline P27 & Female & 22 & 0 & Single & Shared & 3 & Weekly & 2 & yes & $\begin{array}{l}\text { Bedroom, } \\
\text { parents' house, } \\
\text { balcony, kitchen, }\end{array}$ & Sociality \\
\hline
\end{tabular}


Female

32

$0 \quad$ Single

Shared

$0 \quad$ Single

Shared

$0 \quad$ Single

Shared
3 Daily

3 Daily

3 Weekly street, pub, clubs,

on bike

Back yard,

bedroom, DSPW

street, car

Yard, pier,

designated public

spaces, street

Front yard,

street, club,

friend's house,

back yard, nearby

alley

Place with highest degree of PA regarding smoking is given in bold. An asterisk after the participant's code indicates that they had professed to have little to no place attachment regarding their smoking sites. DSPW means designated smoking sites at work. 